Crunkelton, W.S. 1999. Fruit harvesting machine. U.S. Patent No. 5,966,915. U.S. Patent Office, Alexandria, Va.

Florida Dept. of Citrus. 1992. Official rules of the State of Florida Department of Citrus-Part III, Chapters 20-62. Florida Dept. of Citrus, Lakeland.

Florida Dept. of Citrus, 1997. Citrus harvesting training video. Citrus Res. and Education Ctr., Lake Alfred, Fla.

Florida Dept. of Citrus. 2003. Citrus Reference Book. Florida Dept. of Citrus, Lakeland.

Peterson, D.L. 1998. Mechanical harvester for process oranges. Appl. Eng. Agr. $14(5): 455-458$.

Roka, F.M. 2002. Evaluating performance of citrus harvesting systems, 2001-02 season. Florida Dept. of Citrus, Lakeland.

Roka, F.M. 2003. Evaluating performance of citrus mechanical harvesting systems, 2002-03 season. Florida Dept. of Citrus, Lakeland.

Roka, F.M., R. Buker, and J. Burns. 2003. Late season harvesting trial. Florida Dept. of Citrus, Lakeland.

Whitney, J.D. 1995. A review of citrus harvesting in Florida, p. 33-60. Proc. Citrus Eng. Conf., Citrus Res. and Education Ctr., Lake Alfred, Fla.
Harvest

\section{Mechanization Progress and Prospects for Fresh Market Quality Deciduous Tree Fruits}

\section{D.L. Peterson ${ }^{1}$}

AdDitional Index wORDs. machine harvest, labor, apple, peach, sweet cherry

Summary. Deciduous tree fruit crops such as apple (Malus domestica), peach (Prunus persica), and sweet cherry (Prunus avium) are not mechanically harvested for the fresh market. Attempts to mechanically harvest these fruits by mass removal techniques have not been successful due to excessive fruit damage caused during detachment, fall through the canopy, and collection. Robotic harvesters have not been commercially accepted due to insufficient fruit recovery. A U.S. Department of Agriculture-Agricultural Research Service (USDAARS) harvesting concept shows promise for harvesting both fresh market quality apples and sweet cherries. Successful mechanical harvesting of fresh market quality deciduous tree fruit will only occur when plant characteristics and machine designs are integrated into a compatible system. Cultivar characteristics that would facilitate machine harvesting are uniform fruit maturity at harvest, firm fruit that are resistant to mechanical damage, and compact growth habit that produces fruit in narrow canopies and on short/stiff limbs. Engineers must develop new detachment principles that minimize the energy input to effect fruit detachment, and

All programs and services of the USDA are offered on a nondiscriminatory basis with regard to race, color, national origin, religion, sex, age, marital status, or handicap. Mention of trade names or commercial products in this publication is solely for the purpose of providing specific information and does not imply recommendation or endorsement by the U.S. Depart ment of Agriculture.

${ }^{1}$ ASAE Fellow, Agricultural Engineer, USDA Agricultural Research Service, Appalachian Fruit Research Station, Kearneysville, WV. To whom reprint requests should be addressed:USDA, ARS, Appalachian Fruit Research Station, 2217 Wiltshire Road, Kearneysville, WV 25430-2771; voice: (304)725-3451, ext. 324; fax (304) 728-2340; e-mail: dpeterson@afrs.ars.usda.gov develop durable energy-absorbing catching surfaces/conveyors to eliminate damage during collection of the fruit. As technology advances, sorting and sizing systems might be developed that can be operating on the harvester to eliminate culls in the field and deliver only fresh market quality fruit to the packers.

$\mathrm{T}$ The deciduous tree fruit industry is an important segment of U.S. agriculture. In 2001, apples, sweet cherries, and peaches provided incomes for orchards in the U.S. of $\$ 1,553,536,000 ; \$ 286,744,000$; and $\$ 495,067,000$, respectively (USDA, National Agricultural Statistics Service, 2001). However, the limited availability and rising cost of a skilled workforce to harvest this fruit are major concerns of the U.S. fruit industry (Brown, 2003; Hanson, 1999a; Morgan, 2002; Warner, 1997). The gradual reduction of labor supplies and increased tree fruit acreage, particularly in the northwestern U.S., led to shortages in recent years and is expected to worsen in the future. Competition from countries with significantly lower labor costs could force U.S. producers to reduce costs or lose valuable markets. Holt (1999) suggested that increased mechanization could be an effective means of increasing worker productivity and keeping U.S. fruit industries competitive in the world market. Currently, there is no commercial mechanical harvesting of fresh market quality deciduous tree fruits in the U.S. (Sarig et al., 1999).

The objective of this paper is to describe recent research to mechanically harvest fresh market quality apples, sweet cherries, and peaches; cite reasons for lack of success; and speculate on requirements for successful harvest mechanization.

\section{Apple}

Attempts to mechanically harvest apples by mass removal techniques (shake/catch) from freestanding trees have not been successful (Brown et al., 1983; Peterson et al., 1994) due to excessive fruit damage. This damage occurs from 1) excessive apple movement during detachment, causing apple-to-apple, and apple-to-branch contact; 2) apple-to-branch contact when falling; and 3) apple-to-apple contact on the catching surfaces, since most of the apples fall in a short time 
period (3-6 s). Narrow inclined trellis systems for apples (Fig. 1) have been developed to space primary fruiting scaffolds equally along the trellis, and from the bottom to top of the wire support (Robinson and Lakso, 1991; Robinson et al., 1990). In addition to being very productive by improving light distribution within the canopy, these trellised systems may be compatible with mechanical harvesting by providing sites for shaker attachment and an open non-overlapping branching pattern to minimize damage during apple fall. Upadhyaya et al. (1981a, $1981 \mathrm{~b})$ found that impacting inclined apple limbs from below in a direction transverse to the limb nearly eliminated fruit movement during detachment, which should reduce detachment damage. Colorio and Beni (1995) developed a harvesting system for narrow inclined trellises that utilized underlimb impactors and a special catching surface to harvest apples. Harvest trials produced less fruit damage than reported by shake/catch harvesting methods, but the system has not been commercialized.

More recently, Peterson et al. (1999) developed a robotic bulk harvester concept to remove apples grown on narrow inclined trellises. This system combined mechanical harvesting technology, an imaging system, and intelligent adaptive technology to identify individual scaffolds, determine fruit locations, position a rapid displacement actuator (RDA) against a scaffold, and a catching surface under the apples. When executed, the RDA supplied an impulse to rapidly displace the scaffold away from the fruit, causing detachment. Limited field testing demonstrated feasibility of the system with nearly complete fruit removal and fruit quality as good as from hand harvesting. However, they suggested that using a human operator to position and activate the RDA with hydraulic joysticks might be a simpler, more reliable, and easier solution to implement than an imaging system with controlling software. Building on this harvesting concept, Peterson and Wolford (2001, 2002) developed components for a mechanical harvesting system that had an operator using hydraulic joysticks to position the RDA, and active energyabsorbing catching surfaces to collect the fruit (Fig. 2). Trees were trained to a Y-trellis. Mechanical harvesting trials with this system on eight apple

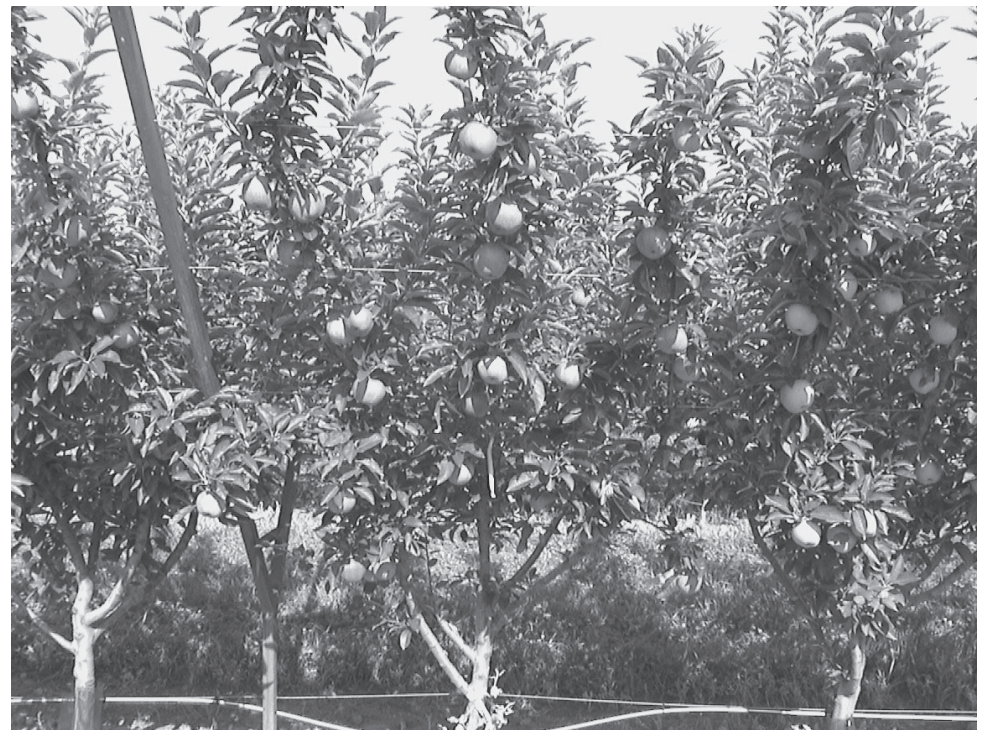

Fig. 1. Side view of "Y" trellis showing orientation of scaffolds and apples.

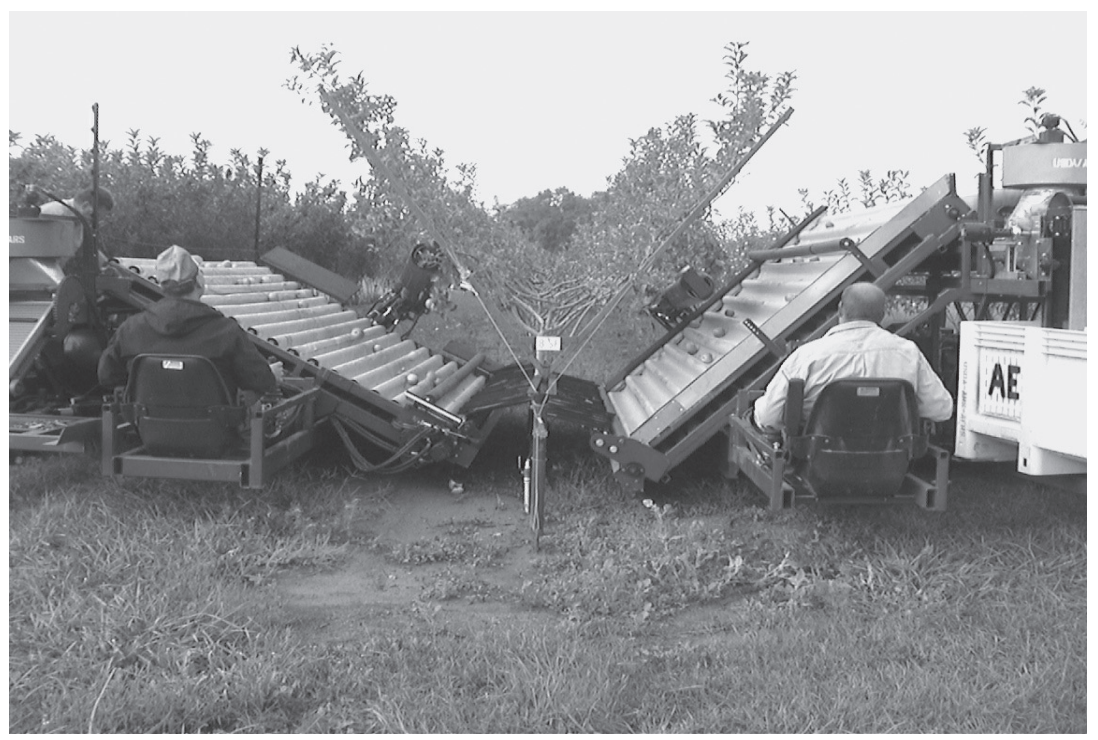

Fig. 2. Rear view of USDA-ARS experimental apple harvester in a "Y" trellised planting. Operators position rapid displacement actuators on scaffold to effect fruit removal. Apples are caught by "soft" moving conveyors and automatically placed in bins.

cultivars yielded $71 \%$ to $90 \%$ fresh market quality (Peterson and Wolford, 2003). Cuts and punctures were the dominant factor in lower fruit grade. In these trials, $20.2 \%$ to $57.2 \%$ of the fruit exhibited stem pulls, which has the potential to cause serious long-term storage problems. In a companion study, Janisiewicz and Peterson (data not published) found that decay on apples with stem pulls was not a serious issue on most cultivars. However, treatment with postharvest biocontrol agents minimized the decay in susceptible cultivars. Peterson and Wolford (2003) also found that cultivar growth habit and hence their adaptability to this harvesting concept varied greatly. The most suitable cultivars had compact growth habits with short fruitful laterals that required minimum training.

Intelligent systems, in the form of robotic harvesters, have been developed to pick individual fruits from trees (Bourely et al., 1990; Grand d'Esnon et al., 1987; Harrell, 1987; Kassay, 1997). However, none of these robotic concepts have been adopted commercially because of low capacity and the inability to locate and harvest all the fruit. Kassay et al. (1997) picked only $25 \%$ to $32 \%$ of the apples from a 
conventional freestanding tree, and felt that a thin hedgerow would be required for successful robotic harvesting. Pellenc (Pellenc S.A., Pertuis, France) has a commercial prototype robotic harvester for apples and oranges (Citrus sinensis). Antoine Bourely, Pellenc Environmental Engineer (personal communication), stated that tests on a 1.2-m-wide, 4.5 -m-high $(3.94 \times 14.76$ $\mathrm{ft}$ ) apple hedgerow resulted in $80 \%$ fruit removal. Five percent of the crop dropped to the ground as other apples were being picked, and $15 \%$ were not accessible to the robot: either hidden to the imaging system, or behind limbs and not reachable by the picking arm. Robotic picking rate was as high as one fruit every $2 \mathrm{~s}$. Despite high fruit quality from the robotic harvesters, this concept has not been commercialized because of the inability to harvest a greater portion of the crop.

In addition to incomplete fruit recovery and excessive damage, variability in individual fruit maturity limits the potential to mechanically harvest apples. In recent years, the trend is for newer cultivars to be multiple pick based on color (Buckner, 1999). This fact makes mechanical harvesting by mass removal even more challenging, since mass removal techniques are not selective in harvesting only mature fruit. Also to date, experimental robotic harvesters have not had the ability to select fruit based on maturity.

\section{Sweet cherry}

The main problems preventing machine harvest of sweet cherries are similar to those described above for apples. Traditionally, the industry has dictated that sweet cherries sold on the fresh market must have stems. Attempts to mechanically harvest sweet cherries with stems have resulted in severe fruit damage due to excessive fruit movement during detachment (Halderson, 1966; Markwardt et al., 1964; Norton et al., 1962).

Innovative growers in the state of Washington (Hansen, 1999b) have developed a system of training and cultural practices designed to be compatible with mechanical harvesting, but the system yields stemless sweet cherries for the fresh market. Test marketing of the stemless sweet cherries found very good consumer acceptance. The timely application of a fruit abscission compound to loosen the fruit-pedicel attachment is required for most cul-

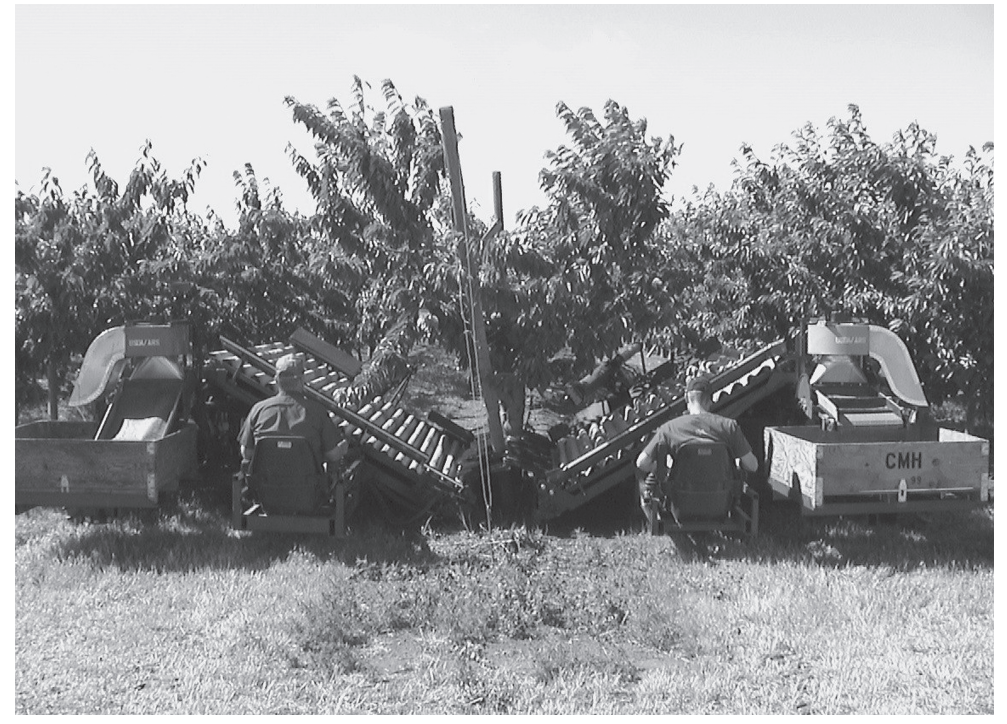

Fig. 3. Rear view of USDA-ARS experimental sweet cherry harvester in a "Y" trellised block. Left and right units are separate mirror images, but operate in conjunction with each other.

tivars. Bukovac et al. (1971) found that ethrel applied 7 to $14 \mathrm{~d}$ before harvest could reduce the fruit-topedicel removal force from $>0.5 \mathrm{~kg}$ $(1.10 \mathrm{lb})$ to $<0.3 \mathrm{~kg}(0.66 \mathrm{lb})$. Tests of the USDA-ARS harvesting concept (Peterson and Wolford, 2001, 2002; Peterson et al., 2003) in commercial orchards (Fig. 3 ) showed promise for harvesting fresh market quality stemless sweet cherries with quality as good as from commercial hand picking. Ethrel was effective in reducing fruit detachment force to the range of 0.15 to $0.23 \mathrm{~kg}(0.331-0.507 \mathrm{lb})$. Field tests showed that a compatible tree-training system is critical for efficient machine operation and optimum fruit quality. With compatible tree architecture, harvest rates ranged from 85 to 158 trees/h with harvester capacity up to $1587.6 \mathrm{~kg} \cdot \mathrm{h}^{-1}(3500 \mathrm{lb} / \mathrm{h})$. A desired tree-training system has 1 ) minimum

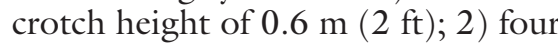
to six scaffolds per tree (two to three per side); 3 ) scaffolds oriented $45^{\circ}$ to $60^{\circ}$ to horizontal; and 4) short, stiff, non-overlapping fruiting laterals along scaffolds. Washington researchers and growers are training new plantings to be compatible with this harvesting concept. If wholesale and retail markets accept stemless sweet cherries, it is expected that mechanical harvesting of fresh market sweet cherries could be commercialized in the next few years.

\section{Peach}

In the 1970s and 1980s researchers in the southeastern U.S. (Diener et al., 1976; Peterson and Monroe, 1977; Peterson et al., 1989; Webb et al., 1973) using shake-catch harvesters demonstrated that peaches could be mechanically harvested with damage levels comparable with hand harvesting. Two key reasons for this success were: 1) trees were trained to either an open center or " $Y$ " with a minimum of overlapping scaffolds, and 2) peaches were very firm (not fully mature) when harvested for the fresh market. However, the necessity for multiple pickings has prevented the commercial adoption of this system. Mass removal of peaches by shaking resulted in either too many overripe or underripe fruit, or both.

\section{Criteria for mechanical harvesting of deciduous tree fruits for the fresh market}

Successful mechanical harvesting of fresh market quality deciduous tree fruit will only occur when plant characteristics and machine designs are integrated into a compatible system.

Cultivar characteristics that would facilitate machine harvesting are 1 ) uniform fruit maturity at harvest (essential for mass removal techniques, desirable for robotic harvesting); 2) firm fruit that are resistant to mechanical damage; and 3) compact growth habit that produces fruit in narrow canopies and on short/stiff limbs (such a structure would also reduce pruning costs).

Tree architectures need to be developed that maintain productivity 
yet place fruit in a "harvestable" position for efficient removal and collection. Fruit need to be positioned in a canopy structure that permits efficient force transmission for minimum fruit movement during detachment, and once detached, have a clear patch to the catching surface. Uniform narrow fruiting canopies will not only reduce fruit damage during harvesting, but also improve machine operating efficiency. Peterson et al. (2003) found that harvest rates with a tree training systems compatible with the machine harvesting were two to three times higher than harvest rates with incompatible tree training systems.

With improved canopy structures, engineers can refine existing detachment principles and develop new principles that minimize the energy input to effect fruit detachment, which will minimize fruit damage. Uniform canopies will also permit catching surfaces to be placed closer to the fruiting zone to minimize drop heights. Durable energy-absorbing catching surfaces/ conveyors still need to be improved to eliminate damage during collection of the fruit. As technology advances, sorting and sizing systems might be developed that can be operating on the harvester to eliminate culls in the field and deliver only fresh market quality fruit to the packers.

\section{Literature cited}

Bourely, A., G. Rabatel, A. Grand d'Esnon, and F. Sevila. 1990. Fruit harvest robotization: 10 years of CEMAGREF experience on apple, grape and orange. Proc. AGENG 90 Conf., Berlin, Germany. p. 178-179.

Brown, G. 2003. Overdue reform, proposed changes to $\mathrm{H} 2 \mathrm{~A}$ program could help produce growers. Veg. Growers News $37(7): 1,12$.

Brown, G.K., D.E. Marshall, B.R. Tennes, D.E. Booster, P. Chen, R.E. Garrett, M. O'Brien, H.E. Studer, R.A. Kepner, S.L. Hedden, C.E. Hood, D.H. Lenker, W.F. Millier, G.E. Rehkugler, D.L. Peterson, and L.N. Shaw. 1983. Status of harvest mechanization of horticultural crops. SP-3. Amer. Soc. Agr. Eng., St. Joseph, Mich.

Buckner, L. 1999. Apple and pear production and planting trend. Good Fruit Grower 50(9):35-38.

Bukovac, M.J., F. Zucconi, V.A. Wittenback, J.A. Flore, and H. Inoue. 1971. Effects of 2-chloroethyl phosphonic acid on development and abscission of maturing sweet cherry (Prunus avium L.). J. Amer. Soc. Hort. Sci. 96:777-781.
Colorio, G. and C.Beni. 1995. A plant-machine combined system for fruit harvesting. Proc. Harvest and Postharvest Technol. for Fresh Fruit and Veg., Guanajuato, Mexico, 20-24 Feb. 1995. p. 248-254.

Diener, R.G., R.E. Adams, P.E. Nesselroad, K.C. Elliott, M. Ingle, and S.H. Blizzard. 1976. Mechanical harvesting of tree fruits in West Virginia. ASAE Paper No. 76-1953. Amer. Soc. Agr. Eng., St. Joseph, Mich.

Grand d'Esnon, A., G. Rabatel, R. Pellenc, and A. Journeau. 1987. Magali-A self-propelled robot to pick apples. ASAE Paper No. 87-1037. Amer. Soc. Agr. Eng., St. Joseph, Mich.

Halderson, J.L. 1966. Fundamental factors in mechanical cherry harvesting. Trans. Amer. Soc. Agr. Eng. 9(5):681-684.

Hansen, M. 1999a. Prepare now for labor shortages. Good Fruit Grower $50(3): 41-42$.

Hansen, M. 1999b. Harris still working on mechanical harvesting. Good Fruit Grower 50(5):51.

Harrell, R. 1987. Economic analysis of a robot citrus harvester in Florida. Trans. Amer. Soc. Agr. Eng. 30(2):298-304.

Holt, J.S. 1999. Implications of reduced availability of seasonal agricultural workers on the labor intensive sector of U.S. agriculture. ASAE Paper \#991095 Amer. Soc. Agr. Eng., St. Joseph, Mich.

Kassay, L. 1997. Results of research of the AUFO 12/9 armed fruit picking robot. ASAE Paper No. 973094, Amer. Soc. Agr. Eng., St. Joseph, Mich.

Markwardt, E.D., R.W. Guest, J.C. Cain, and R.L. LaBelle. 1964. Mechanical cherry harvesting, Trans. Amer. Soc. Agr. Eng. 7(1):70-74.

Morgan, K. 2002. U.S. immigration policy is not a governmental success. Fruit Grower News $41(9): 35$.

Norton, R.A., L.L. Claypool, S. Leonard, P. Adrain, R. Fridley, and F. Charles. 1962. Mechanical harvest of sweet cherries. Calif. Agr. 16(5):8-10.

Peterson, D.L., B.S. Bennedsen, W.C. Anger, S.D. Wolford. 1999. A systems approach to robotic bulk harvesting of apples. Trans. Amer. Soc. Agr. Eng. 42(4):871-876.

Peterson, D.L., S.S. Miller, and J.D. Whitney. 1994. Harvesting semidwarf freestanding apple trees with an over-therow mechanical harvester. J. Amer. Soc. Hort. Sci. 119:1114-1120.

Peterson, D.L. and G.E. Monroe. 1977. Continuously moving shake-catch harvester for tree crops. Trans. Amer. Soc. Agr. Eng. 20(2):202-205, 209.
Peterson, D.L., R. Scorza, S.S. Miller, and D.M. Glenn. 1989. Evaluating freshmarket peaches for once-over mechanical harvesting. HortScience 24(3):446-448.

Peterson, D.L., M.D. Whiting, and S.D. Wolford. 2003. Fresh market quality tree fruit harvester, Part I: Sweet cherry. Appl. Eng. Agr. 19(5):539-543.

Peterson, D.L. and S.D. Wolford. 2001. Mechanical harvester for fresh market quality stemless sweet cherries. Trans Amer. Soc. Agr. Eng. 44(3):481-485.

Peterson, D.L. and S.D. Wolford. 2002. Mechanical harvester for fresh market quality stemless sweet cherries, p. 123-127. In: M. Zude, B. Herold, and M. Geyer (eds.). Proc. $6^{\text {th }}$ Intl. Symp. on Fruit, Nut, and Veg. Production Eng. Potsdam, Germany, 11-14 Sept. 2001.

Peterson, D.L. and S.D. Wolford. 2003. Fresh market quality tree fruit harvester, Part II: Apples. Appl. Eng. Agr. 19(5):545-548.

Robinson, T. and A. Lakso. 1991. Bases of yield and production efficiency in apple orchard systems. J. Amer. Soc. Hort. Sci. 116:188-194.

Robinson, T.L., W.F. Millier, J.A. Throop, S.G. Carpenter, and A.N. Lakso. 1990. Mechanical harvestability of Y-shaped and pyramid-shaped 'Empire' and 'Delicious’ apple trees. J. Amer. Soc. Hort. Sci. 115:268-274.

Sarig, Y., J.F. Thompson, and G.K. Brown. 1999. The status of fruit and vegetable harvest mechanization in the US. ASAE Paper No. 91098, Amer. Soc. Agr. Eng., St. Joseph, Mich.

USDA, National Agricultural Statistics Service. 2001. Chapter V, Statistics of fruits, tree nuts, and horticultural specialties. 18 Aug. 2003. <http://www.usda. gov/nass/pubs/agr01/01_ch5.pdf>

Upadhyaya, S.K., J.R. Cooke, R.A. Pellerin, and J.A. Throop. 1981a. Limb impact harvesting, Part II: Experimental approach. Trans. Amer. Soc. Agr. Eng. 24(4):864-867.

Upadhyaya, S.K. and J.R. Cooke. 1981b. Limb impact harvesting, Part III: Model studies. Trans. Amer. Soc. Agr. Eng. 24(4):868-871, 878.

Warner, G. 1997. Work force shrinks as border patrol moves in. Good Fruit Grower. 48(10):16-17.

Webb, B.K., C.E. Hood, W.H. Jenkins, and C.D. Veal. 1973. Development of an over-the-row peach harvester. Trans. Amer. Soc. Agr. Eng. (16):450-455. 